7. Reprod. Fertil. (1965) 10, 189-196

\title{
EXPERIMENTAL ECTOPIC IMPLANTATION OF EGGS AND EARLY EMBRYOS IN GUINEA-PIGS
}

\author{
K. P. BLAND AND B. T. DONOVAN \\ Department of Neuroendocrinology, Institute of Psychiatry, \\ The Maudsley Hospital, London \\ (Received 26th November 1964)
}

\begin{abstract}
Summary. Successful primary abdominal implantation and development has been induced in the guinea-pig by transection of the oviducts 1 to 3 days after mating although attempts made to induce tubal implantation by ligature of the utero-tubal junction failed.

Development also took place in four out of eighteen pre-implantation eggs (aged 4 to 5 days post coitum) transplanted into the kidney or abdominal muscle. In six cases, where post-implantation conceptuses (aged $9 \frac{1}{2}$ and 12 days post coitum) were transplanted into the spleen, testes or anterior chamber of the eye, growth and differentiation was observed on each occasion.
\end{abstract}

\section{INTRODUCTION}

Study of the mechanisms concerned in the implantation of a fertilized ovum is of considerable importance for medical, veterinary and sociological reasons. It is known that normal implantation involves a series of interactions between the blastocyst and the endometrium. Nervous, hormonal and nutritional factors participate in this chain of events but the precise role of each is poorly understood (Böving, 1963). Considerable attention has been paid to the analysis of these processes in the rat, mouse and rabbit for these species produce a large number of eggs and are thus convenient for laboratory study. On the other hand study of the guinea-pig has been largely neglected, although the finding that artificial ova (glass beads) inserted into the uterus do not produce deciduomata in the guinea-pig as they do in the rat (Blandau, 1949b) suggests that there are differences in the mechanism of implantation in the two species.

Examination of the developmental capacities of the blastocyst is facilitated by the experimental induction of ectopic implantation. The relative contributions of the uterus and the blastocyst to such processes as the production of hormones by the conceptus can also be studied in this way. Previous investigations concerned with the ectopic development of the blastocyst have employed the rat and mouse (Nicholas, 1934, 1942; Runner, 1947; Fawcett, Wislocki \& Waldo, 1947; Fawcett, 1950; Jones, 1951; Kirby, 1960, 1963a, b), but only a single case of experimentally induced extra-uterine implantation (Loeb, 1914, 1915) and one instance of a naturally occurring ectopic pregnancy (Araujo, 1964) have been described in the guinea-pig. The present paper records the results obtained in a series of attempts to produce implantation and 
development at ectopic sites in this species by confining the fertilized eggs to the fallopian tubes, by causing them to enter the abdominal cavity or by transferring conceptuses from one animal to various locations in another.

\section{Animals}

\section{METHODS}

Adult guinea-pigs ( 550 to $950 \mathrm{~g}$ ) from a mixed stock were employed in this study and both nulliparous and multiparous animals were used. Where necessary the progress of the oestrous cycle of the females was followed by daily examination of the vaginal closure membrane and, if the vagina was open, a smear taken. Animals to be mated were caged with males overnight and the presence of spermatozoa in a vaginal smear was taken as the criterion for the occurrence of copulation.

\section{Surgical procedures}

All operations were performed under Nembutal anaesthesia (Pentobarbitone sodium, Abbott Laboratories, $40.2 \mathrm{mg} / \mathrm{kg}$ ).

Production of tubal implantation. In an attempt to promote implantation within the oviducts, the right fallopian tube in four animals was transected at its junction with the uterine horn and the uterine end of the tube ligated. The left fallopian tube remained intact. The operation was performed during the first 3 days after mating before the entry of the fertilized eggs into the uterus.

In four other animals, both fallopian tubes were ligated at the utero-tubal junction between 1 and 3 days after mating.

Production of primary abdominal implantation. In seven guinea-pigs, both fallopian tubes were transected at various times between $12 \mathrm{hr}$ and 5 days after mating in order to allow the entry of fertilized eggs into the abdominal cavity where implantation might occur. The animals were killed 18 to 20 days later ( 57 days in one case) and the abdomen searched for implantation sites as indicated by small haemorrhagic areas.

To exclude the possibility that fertilized eggs discharged into the abdominal cavity might nevertheless enter the uterus, the tubal end of each horn was ligated in nine animals and the fallopian tubes then transected at various times between $12 \mathrm{hr}$ and 4 days after mating. The animals were killed 13 to 22 days after the operation and examined for possible implantation sites.

Transfer of morulae, blastocysts or implanted conceptuses to selected locations. Fertilized eggs (4- or 5-day morulae and 5-day blastocysts) and early embryos (91- and 12-day implanted conceptuses), collected from donor females killed by concussion or by an overdose of Nembutal, were inserted beneath the capsule of the kidney to a pocket in contact with abdominal muscle, or to the spleen, testis or anterior chamber of the eye of male or non-pregnant female hosts (Table 2). The hosts were killed between 6 and 22 days later, except for one animal which was allowed to live for 62 days, and the development of the eggs or conceptuses assessed. The eggs were flushed from the uterus with physiological saline at room temperature whilst the implanted conceptuses were carefully dissected from the decidual tissue. In the majority of cases the specimens, after identification, were picked up in a glass micropipette, held in a Singer micro- 
dissection apparatus (Mark 1) and attached to an Agla micrometer syringe (Kirby, 1962), and transferred to the host animal. On other occasions a simple micropipette was used.

\section{Histological procedure}

At autopsy the animals were killed either by concussion or by an overdose of Nembutal and any tissues needed for histological examination fixed in $10 \%$ neutral formalin. In a few instances alcoholic Bouin's fluid was used. The fixed tissues were subsequently embedded in paraffin wax, serially sectioned at $10 \mu$ and stained, usually with haematoxylin and eosin.

TABLE 1

OCCURRENCE OF ECTOPIC IMPLANTATION AFTER TRANSECTION OF OVIDUCTS

\begin{tabular}{|c|c|c|c|c|c|}
\hline Animal $\mathcal{N} o$ & $\begin{array}{c}\text { No. days } \\
\text { after } \\
\text { copulation }\end{array}$ & $\begin{array}{c}\text { Pre-operative } \\
\text { cycle } \\
\text { (days) }\end{array}$ & $\begin{array}{c}\text { Subsequent } \\
\text { cycle } \\
\text { (days) }\end{array}$ & $\begin{array}{l}\text { Interval between } \\
\text { copulation and } \\
\text { autopsy (days) }\end{array}$ & $\begin{array}{c}\text { No. } \\
\text { ectopic } \\
\text { implantations }\end{array}$ \\
\hline $\begin{array}{l}321 \\
435 \\
309 \\
312 \\
452 \\
247 \\
301 \\
339 \\
314\end{array}$ & $\begin{array}{l}0 \\
0 \\
1 \\
1 \\
2 \\
3 \\
3 \\
3 \\
4\end{array}$ & $\begin{array}{l}\frac{16}{16} \\
\frac{17}{16} \\
\frac{17}{16}\end{array}$ & $\begin{array}{r}18 \\
17 \\
17 \\
17 \\
16 \\
17 \\
- \\
26\end{array}$ & $\begin{array}{l}21 \\
22 \\
17 \\
18 \\
22 \\
16 \\
18 \\
13 \\
21\end{array}$ & $\begin{array}{l}0 \\
0 \\
0 \\
2 \\
1 \\
1 * \\
1 \\
0 \dagger \\
0 \dagger\end{array}$ \\
\hline
\end{tabular}

* Early tubal implantation also present.

$\dagger$ Embryos present in uterus.

\section{Production of tubal implantation}

\section{RESULTS}

Tubal pregnancies failed to develop in any animal in which ligation of the oviducts was carried out, but all four animals with an intact left fallopian tube became pregnant in the left horn of the uterus.

\section{Production of primary abdominal implantation}

There was no evidence of ectopic implantation in any of the seven animals in which both fallopian tubes were transected without ligation of the uterine horn. Two animals operated on the 4th and one on the 5th day after mating were pregnant and were carrying three or four foetuses in the uterus.

Two of the nine animals in which the oviducal ends of the uterus were ligated before transection of the oviducts were also found to be pregnant (Table 1). They had been operated upon 3 and 4 days after mating and were carrying two and three foetuses respectively. There were no extra-uterine implantations in these two guinea-pigs. Five instances of extra-uterine implantation were found in the remaining seven animals of this group. Two ectopic implantations occurred in one animal (312) and were located in the mesentery of the gut and in the muscle adjacent to the right ovary. In the latter site a well-developed amnion and yolk sac had formed but only trophoblast with undifferentiated 
mesenchymal cells had developed in the mesentery. In the other animals implantations occurred in the mesentery of the oviduct, the external wall of the oviduct and the muscle of the abdominal wall. Trophoblast was produced in all cases but the extent to which it invaded the surrounding tissue varied. The nontrophoblastic component of these implants was restricted to a mesenchyme-like tissue which probably represents abortive yolk sac cells and was present in considerable quantity in animal 452. The amount of extravasated blood

TABLE 2

RESULTS OF TRANSFER OF EGGS AND CONGEPTUSES TO ECTOPIC SITES

\begin{tabular}{|c|c|c|c|c|c|c|c|}
\hline $\begin{array}{c}\text { No. } \\
\text { host } \\
\text { animal }\end{array}$ & $\begin{array}{c}\text { Age } \\
\text { of } \\
\text { conceptus* } \\
\text { (days) }\end{array}$ & Stage & $\begin{array}{c}\text { No. } \\
\text { trans- } \\
\text { planted }\end{array}$ & $\begin{array}{l}\text { Transplant } \\
\text { site }\end{array}$ & $\begin{array}{c}\text { Post- } \\
\text { operative } \\
\text { interval } \\
\text { (days) }\end{array}$ & $\begin{array}{c}\text { Length of } \\
\text { post- } \\
\text { operative } \\
\text { cycle } \dagger \\
\text { (days) }\end{array}$ & $\begin{array}{c}\text { Successful } \\
\text { development }\end{array}$ \\
\hline 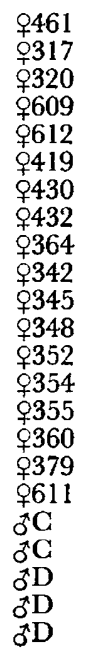 & $\begin{array}{l}4 \\
4 \\
4 \\
4 \frac{1}{2} \\
4 \frac{1}{2} \\
5 \\
5 \\
5 \\
5 \\
5 \\
5 \\
5 \\
5 \\
5 \\
5 \\
5 \\
5 \\
9 \frac{1}{2} \\
9 \frac{1}{2} \\
9 \frac{1}{2} \\
12 \\
12 \\
12\end{array}$ & $\begin{array}{l}\text { Eggs } \downarrow \\
\text { Eggs } \\
\text { Morulae } \\
\text { Morula } \\
\text { Morula } \\
\text { Eggs } \\
\text { Eggs } \\
\text { Eggs } \\
\text { Blastocysts } \\
\text { Morulae } \\
\text { Various } \\
\text { Egg } \\
\text { Blastocysts } \\
\text { Eggs } \\
\text { Eggs } \\
\text { Eggs } \\
\text { Eggs } \\
\text { Impl. embryo } \\
\text { Impl. embryo } \\
\text { Impl. embryo } \\
\text { Impl. embryo } \\
\text { Impl. embryo } \\
\text { Impl. embryo }\end{array}$ & $\begin{array}{l}3 \\
4 \\
4 \\
1 \\
1 \\
2 \\
2 \\
4 \\
2 \\
4 \\
4 \\
1 \\
2 \\
3 \\
4 \\
3 \\
3 \\
1 \\
1 \\
1 \\
1 \\
1 \\
1\end{array}$ & $\begin{array}{l}\text { Muscle } \\
\text { Kidney } \\
\text { Kidney } \\
\text { Kidney } \\
\text { Kidney } \\
\text { Muscle } \\
\text { Muscle } \\
\text { Muscle } \\
\text { Muscle } \\
\text { Kidney } \\
\text { Kidney } \\
\text { Kidney } \\
\text { Kidney } \\
\text { Kidney } \\
\text { Kidney } \\
\text { Kidney } \\
\text { Kidney } \\
\text { Ant. eye } \\
\text { Spleen } \\
\text { Testis } \\
\text { Spleen } \\
\text { Testis } \\
\text { Testis }\end{array}$ & $\begin{array}{l}22 \\
13 \\
17 \\
= \\
62 \\
16 \\
22 \\
15 \\
15 \\
11 \\
6 \\
15 \\
12 \\
12 \\
13 \\
13 \\
12 \\
11 \\
11 \\
11 \\
11 \\
11\end{array}$ & $\begin{array}{l}\overline{16} \\
17 \\
\overline{-} \\
36 \\
17 \\
17 \\
17 \\
18 \\
15 \\
16 \\
\overline{17} \\
\overline{17} \\
= \\
= \\
- \\
-\end{array}$ & $\begin{array}{l}\text { No } \\
\text { No } \\
\text { Yes } \\
\text { No } \\
\text { No } \\
\text { No } \\
\text { No } \\
\text { No } \\
\text { Yes } \\
\text { Yes } \\
\text { No } \\
\text { No } \\
\text { No } \\
\text { Yes } \\
\text { No } \\
\text { No } \\
\text { No } \\
\text { Yes } \\
\text { Yes } \\
\text { Yes } \\
\text { Yes } \\
\text { Yes } \\
\text { Yes }\end{array}$ \\
\hline
\end{tabular}

* Day spermatozoa found in vaginal smear taken as Day 1.

$\uparrow$ Average length normal oestrous cycle 15 to 17 days.

$\mp$ Eggs-actual developmental stage not recorded.

associated with the implantation also varied from site to site. In guinea-pig 247 (Pl. 1, Fig. 1) implantation had occurred on the external surface of the right oviduct and had resulted in the proliferation of trophoblast. The oviduct also contained an egg which had segmented to the 4-cell stage and an implanting egg. The latter appeared to be a blastocyst undergoing elongation during the early attachment phase of implantation but which had become torn away from the mucosa of the tube during fixation (Pl. 1, Fig. 1). It was approximately equivalent to a normal 7- or 8-day conceptus. Since the animal was killed 19 days after mating, development of this egg was undoubtedly delayed. A concentration of host connective tissue around the invasive edge of trophoblast, termed 'pseudodeciduoma' by Jollie (1961), was noted whenever the implantation involved connective or adipose tissue.

The vaginal cycle was followed in three animals showing ectopic develop- 


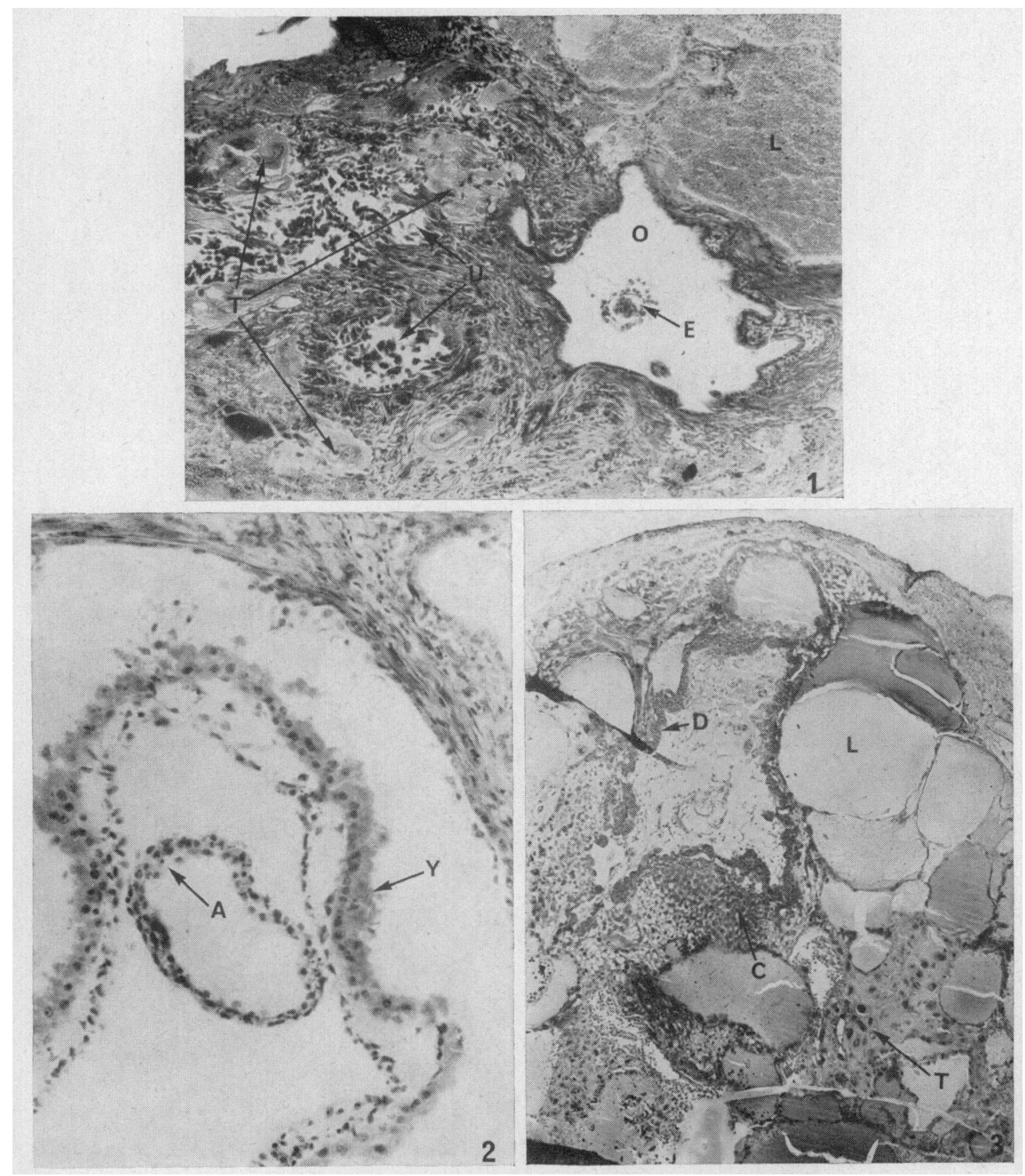

FIg. 1. Guinea-pig 247. Implantation into the external wall of the oviduct. The tubal lumen contains an implanting egg. E: tubal egg; L: lacuna containing extravasated blood; O: lumen of oviduct; $\mathrm{T}$ : invasive trophoblast; $\mathrm{U}$ : unorganized extra-embryonic tissue. $\times 165$.

FIG. 2. Guinea-pig 312. Implantation into muscle adjacent to the right ovary, with differentiated membranes present. A: amnion; Y: yolk sac. $\times 165$.

FIG. 3. Guinea-pig D. Development of 12-day conceptus in spleen. Note differentiated placental trophoblast. C: compact syncytiotrophoblast; D: delimiting layer of trophoblast; L: lacunae containing extravasated blood; $T$ : invasive trophoblast. $\times 16 \cdot 5$.

(Facing p. 192) 
ment of eggs and, in all, a normal oestrous vaginal smear was observed 16 or 17 days after the last preoperative oestrus.

\section{Transfer of eggs and conceptuses to selected sites}

Development of fertilized eggs transferred to the left kidney was observed in three out of twelve female guinea-pigs (Table 2). Development also occurred in one of five guinea-pigs in which eggs were inserted into a pocket made in the abdominal muscle (Pl. 1, Fig. 2). Although up to four eggs were introduced into each animal, differentiation of but a single egg appeared to have occurred in each case. Trophoblast and extravasated blood were present in all four successful grafts. Mesenchyme-like cells were present in two of the grafts to the kidney $(320,342)$ and the first stages of differentiation of the embryonic membranes could be made out in guinea-pig 354. Phagocytosis of extravasated erythrocytes by trophoblast cells appeared to be taking place in guineapig 364.

In contrast to the poor rate of success achieved with the transfer of eggs, all of six conceptuses dissected from the endometrium survived transplantation. One conceptus was placed in the anterior chamber of an eye of a female (611); a male guinea-pig (C) acted as host to one conceptus inserted into the spleen and another in the testis, whilst a second male (D) received a conceptus in the spleen and one in each testis. Of these, the graft to the eye chamber developed least and 12 days later consisted solely of a small quantity of trophoblast. In the male guinea-pig $\mathrm{G}$ implantation into the spleen had produced a well-organized trophoblast which had the histological appearance of a functional placenta although it was difficult to identify individual embryonic membranes. The implant located in the testis of this same guinea-pig had produced only trophoblast. This trophoblast usually surrounded blood-filled cavities containing much cellular debris. A layering effect on the part of the cells bordering the invading trophoblast was very well defined and probably indicates lysis of the host tissue (Kirby, 1963b; Billington, 1964). Multinucleated spermatids were also to be found. A well-organized trophoblast with some development of the extra-embryonic membranes was also present in the spleen of guinea-pig D where the aspect of a placenta was again produced (Pl. 1, Fig. 3). Both testes of this animal also contained active trophoblast in which many small lakelets of blood were incorporated, but only one of the grafts contained developing embryonic membranes. Multi-nucleated spermatids and the layering effect indicative of lysis were again evident.

Normal oestrus, as indicated by vaginal smears, occurred 17, 17 and 18 days after the last preoperative oestrus in three animals containing developing eggs (320, 364 and 342 respectively).

\section{DISGUSSION}

Evidence has been presented to show that the production of primary abdominal implantation and development of the conceptus is possible at various extrauterine locations in the guinea-pig. These findings substantiate the single case documented by Loeb $(1914,1915)$ and that of a naturally occurring abdominal pregnancy in the guinea-pig by Araujo (1964). The uterus was opened longi- 
tudinally by Loeb (1914) 2 days $16 \mathrm{hr}$ after copulation, and the animal killed 18 days after mating. A young embryo, with structures resembling 'the neural canal, coelomic and enteric cavities and the anlage of the blood vessels', was found attached to the peritoneal side of the left horn of the uterus near the fallopian tube. Placental formations were present but the development of the embryo was grossly delayed. Primary abdominal implantation appeared likely in this instance. Araujo (1964) on the other hand, found a completely developed foetus in the abdominal cavity. The foetus was attached to the abdominal wall and omentum but was considered to represent a secondary abdominal pregnancy following rupture of the uterine wall at the initial site of implantation. A normally differentiating embryo was never found in the present experiments. There appeared to be a marked degree of imbalance in the development of the trophoblast and extra-embryonic membranes, whilst the degree of proliferation and invasion by the trophoblast varied considerably from one implantation site to another. It is possible, as Loeb (1914) suggested, that these disturbances in development were due to the absence of the decidual response of the uterine endometrium to implantation. The occurrence of normal uterine pregnancies after section and ligation of the fallopian tubes indicates that the operation performed was not detrimental to the development of the conceptus.

A lack of success in inducing tubal pregnancy in the guinea-pig by ligation of the oviducts has previously been reported by Mandl \& Schmit (1898) and by Loeb \& Hunter (1908). The latter workers used sixteen animals and performed the operation either within the first $28 \mathrm{hr}$ post coitum or on the 2 nd day.

The number of implantations of morulae or blastocysts observed in the present experiments was too small for generalizations to be made concerning the degree of development or for useful comparison with other species, although it is clear that differentiation was impaired. The youngest ectopic conceptus studied (in 354) was 17 days old but showed signs only of differentiation of embryonic membranes. Embryos of this age normally have progressed to the twenty-nine somite stage and five divisions of the brain are visible (Harman \& Prickett, 1932; Scott, 1937). The conceptus of guinea-pig 354 corresponded approximately to a stage of not more than 11 to 12 days of age. On the other hand, to judge from observations made in guinea-pig 247, development of an extra-uterine conceptus would seem to surpass that of a tube-locked egg.

Successful abdominal implantation following disconnexion of the oviducts from the uterus and ligation of the entry to the uterus has previously been obtained in rats by Nicholas (1934) in three out of thirty-five animals and by Jollie (1961) in eleven out of 259 experiments. McLaren \& Tarkowski (1963) were able to produce abdominal implantation in mice by introducing eggs into the peritoneal cavity (two of 180 eggs developed) while Fawcett et al. (1947) induced six such implantations in fourteen mice by transecting the oviducts. The higher rate of success (four out of seven animals) in inducing abdominal implantation in guinea-pigs by this means may be due to the greater ability of the guinea-pig blastocyst to penetrate the peritoneum. It has been demonstrated by Blandau (1949b) that the blastocyst of the guinea-pig can cause lysis of a protein substrate, whereas this ability is lacking in that of the rat. Jollie (1961) considered that the incidence of successful implantation was increased 
by flushing the selected host site with a solution of histamine with the intention of inducing some degree of inflammation. Fawcett et al. (1947) and McLaren \& Tarkowski (1963) have drawn attention to the fact that mouse eggs will only implant on a previously traumatized peritoneal surface.

The high degree of success following the transplantation of $9 \frac{1}{2}-$ and 12-day conceptuses (post-implantation) may be due to the fact that tissue proliferation was already underway or to the previous loss of the zona pellucida or oolemma. The latter explanation is unlikely since it has been shown by Blandau (1949a) that pre-implantation attachment of the blastocyst to the endometrium in the guinea-pig occurs prior to the loss of the oolemma, and thus differs from the situation in the majority of animals, whilst the proteolytic activity of the

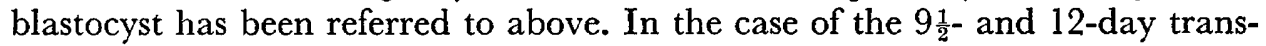
plants no derivatives of the embryonic shield were discovered. This may signify that the embryonic shield becomes more sensitive to interference than the rest of the conceptus once implantation in utero has taken place.

It is noteworthy that the occurrence of ectopic implantation appeared to be without effect on the timing of the next oestrous period, a phenomenon which stands in contrast to the normal situation where intra-uterine implantation appears to prevent the occurrence of oestrus some 10 days later. Loeb (1914) reported that, in his case of extra-uterine pregnancy, ovulation had taken place approximately 15 days after the preceding copulation despite the presence of a young embryo. An explanation of this difference is not immediately available but might lie in the reduced quantity of trophoblast tissue elaborated by the extra-uterine growth, or in the lack of embryo-uterine interaction such as that causing a decidual response. Kirby (personal communication) has also noted that extra-uterine development of eggs in mice is without effect on the oestrous cycle.

\section{ACKNOWLEDGMENTS}

The authors wish to thank Dr D. R. S. Kirby of the Department of Zoology, Oxford University, most warmly for his advice and valuable help and guidance in improving their egg-transplantation technique. Grateful acknowledgment is made to the Population Council for the research grant which supported this work.

\section{REFERENCES}

Araujo, P. (1964) A case of ectopic abdominal pregnancy in guinea-pig. Lab. Anim. Care, 14, 1. Billington, W. D. (1964) Extra-uterine development of mouse trophoblast. F. Reprod. Fertil. 8, 274. Brandau, R. J. (1949a) Observations on implantation of the guinea-pig ovum. Anat. Rec. 103, 19.

Biandau, R. J. (1949b) Embryo-endometrial interrelationship in the rat and guinea-pig. Anat. Rec. $104,331$.

Böving, B. G. (1963) Implantation mechanisms. Conference on Physiological Mechanisms Concerned with Conception, 1959, chap. 7. Ed. G. G. Hartman. Pergamon Press, New York.

FAwcetr, D. W. (1950) The development of mouse ova under the capsule of the kidney. Anat. Rec. 108,71 .

Fawcett, D. W., Wislocki, G. B. \& Waldo, C. M. (1947) The development of mouse ova in the anterior chamber of the eye and in the abdominal cavity. Amer. F. Anat. 81, 413.

Harman, M. T. \& Prickett, M. (1932) The development of the external form of the guinea-pig (Cavia cobaya) between the ages of eleven days and twenty days of gestation. Amer. F. Anat. 49,351 . 
JolLIE, W. P. (1961) The incidence of experimentally produced abdominal implantations in the rat. Anat. Rec. 141, 159.

JoNEs, I. C. (1951) Endocrine effects in the virgin female host of fertilized mouse ova developing in extra-uterine sites. F. Endocrin. 7, Ixiii.

KrRBY, D. R. S. (1960) Development of mouse eggs beneath the kidney capsule. Nature, Lond. 187, 707.

KIRBY, D. R. S. (1962) The effect of the uterine environment on the development of mouse eggs. 7. Embryol. exp. Morph. 10, 496.

KIRBY, D. R. S. (1963a) Development of the mouse blastocyst transplanted to the spleen. F. Reprod. Fertil. 5, 1.

KIRBY, D. R. S. (1963b) The development of mouse blastocysts transplanted to the scrotal and cryptorchid testis. F. Anat. 97, 119.

Loeb, L. (1914) The experimental production of an early stage of extra-uterine pregnancy. Proc. Soc. exp. Biol., N.Y. 11, 103.

LOEB, L. (1915) An early stage of an experimentally produced extra-uterine pregnancy and the spontaneous parthenogenesis of the eggs in the ovary of the guinea-pig. Biol. Bull., Woods Hole, $28,59$.

Loeb, L. \& Hunter, J. W. (1908) Experiments concerning extra-uterine pregnancy and the influence of operation on the course of pregnancy. Univ. Pennsylvania med. Bull. 21, 294.

Mande, L. \& Schmit, H. (1898) Beiträge zur Aetiologie und pathologischen Anatomie der Eileiterschwangerhaften. Arch. Gynäk. 56, 401.

MaLaren, A. \& Tarkowski, A. K. (1963) Implantation of mouse eggs in the peritoneal cavity. $\mathcal{F}$. Reprod. Fertil. 6, 385.

Nicholas, J. S. (1934) Experiments on developing rats. I. Limits of foetal regeneration; behavior of embryonic material in abnormal environments. Anat. Rec. 58, 387.

Nicholas, J. S. (1942) Experiments on developing rats. IV. Growth and differentiation of eggs and eggcylinders when transplanted under kidney capsule. F. exp. Zool. 90, 41.

Runner, M. N. (1947) Development of mouse eggs in the anterior chamber of the eye. Anat. Rec. 98, 1.

ScotT, J. P. (1937) The embryology of the guinea-pig. I. A table of normal development. Amer. $\mathcal{F}$. Anat. 60, 397. 